\title{
MOBILIZATION OF CARDIOVASCULAR FUNCTION AT ONSET OF EXERCISE AND PECULIARITIES OF RECOVERY IN DEPENDENCE ON THE TYPE OF ADAPTATION
}

\author{
Alfonsas Buliuolis, Jonas Poderys, Mindaugas Ežerskis, Kristina Poderytė, Birutė Miseckaitė
} Lithuanian Academy of Physical Education, Kaunas, Lithuania

\begin{abstract}
Alfonsas Buliuolis. PhD in Biomedical Sciences. Lecturer at the Department of Individual Kinds of Sports, Lithuanian Academy of Physical
\end{abstract} Education. Research interests - control of runners' training process.

\begin{abstract}
The objective of this study was to compare the peculiarities of the mobilization of cardiovascular function at onset of exercise test in dependence on the type of adaptation to physical loads. The study participants were 17 voluntary students who were not engaged in the sport training; 21 — endurance group; 19 - sprint group and 21 - combativesport group (box, judo and wrestling). The subjects underwent: 1) a Roufier test (30 squats per 45 seconds); 2) a 30second duration maximal vertical jump test, 3) a bicycle ergometry of incremental increase in provocative workload (graded stress). A computerized ECG system "Kaunas-Workload" was employed for 12 lead ECG recording and analysis during the performance of workloads. A computerized program allowed to measure the ratio of JT and RR intervals $(J T / R R)$ and the velocity of adaptation of cardiovascular system to exercise, i.e. the index of velocity of adaptation $\left(V_{A d}\right)$, by the calculation of the difference between the relative changes of JT interval and RR interval as a difference: $V_{A d}=\left(J T_{i} / J T_{0}\right) 100 \%-\left(R R_{i} / R R_{0}\right) 100 \%$.

The results obtained during the study show that the velocity of adaptation at onset of exercise depends on the residual effects of training but not on the type of exercise-test. The fastest adaptation at onset of exercise was in sprint group $(16.3 \pm 1.33 \%)$. The values of velocity of adaptation in endurance group were $19.8 \pm 1.34 \%$. The difference between sprint and endurance cohorts was statistically significant $(p<0.05)$. The velocity of adaptation in the group of nonathletes was the slowest $-21.4 \pm 1.33 \%$. There were no differences in the ratio JT interval and RR interval (JT / RR between cohorts at the end of graded stress, i.e. when maximal mobilization of muscular and cardiovascular systems was obtained. On the other hand the greatest difference between cohorts was revealed in a 30-second all-out maximal vertical jump test. The greatest values were in the group of non-athletes and the least in endurance group. The difference between these cohorts was statistically significant $(p<0.05)$. Conclusions: 1 -The velocity of adaptation of cardiovascular system at onset of exercise depends on the type of adaptation to exercise type. A faster adaptation at onset of exercise is rather characteristic of sprint and combative sports than representatives of endurance or nonathletes. 2 - The change in ratio of JT interval and RR interval (JT / RR) of ECG allows to assess the dynamics of mobilization of cardiovascular system during the workouts. $3-$ A significant property of recovery after physical loads is an adequate sequence of recovery of cardiovascular system functional indicators and this sequence does not depend on the type of adaptation to exercise. The faster recovery is the ratio JT / RR, then recovery of heart rate (RR interval), then - JT interval.
\end{abstract}

Keywords: cardiovascular system, adaptation, recovery, JT interval.

\section{INTRODUCTION}

At the onset of exercise a lot of physiological systems adapt to the variations of load. Consequently, a number of indices exist for the measurement of response to workload. In practice, the response to exercise can be evaluated by measuring the changes during exercising of one or another system (Hughson, Tschakovsky, 1999; Hedelin et al., 2000; Porter et al., 2001; Rothe, Gersting, 2002). Recently, more frequent research has been carried out to examine the response of body to exercise as an integral impact on the body (Ursino, 1998; Biggiero, 2001). The cardiovascular system is one of the holistic systems of the human body, that is why the reactions of cardiovascular system to constant-load test or all-out test allows to assess the functional peculiarities of the body (Vainoras, 2002). 
The fast mobilization of body functions at onset of exercise is very important in many kinds of sport and there are a lot of situations in competitive sport when this ability is determinant factor or important element of functional capability (Платонов, 2004). The objective of this study was to compare the peculiarities of mobilization of cardiovascular function at onset of exercise tests and recovery in dependence on the type of adaptation to physical loads.

\section{MATERIAL AND METHODS}

The study participants were 17 voluntary students who were not engaged in the sport training (aged 20.9 \pm 1.21 , body mass index $22.3 \pm 0.38$ ); high-skilled athletes (all participants were members of various national teams), i. e. 23 - endurance group; 19 - sprint group and 21 - combativesport group (box, judo and wrestling).

The subjects underwent: 1) a Roufier test (30 squats per 45 seconds); 2) a 30-second duration maximal vertical jump test, 3 ) a bicycle ergometry of incremental increase in provocative workload (graded stress). During the bicycle ergometry the subjects underwent a $50 \mathrm{~W}$ increase in workload every 60 seconds ( 60 revolutions / $\mathrm{min}$ ) and they exercised to a predetermined goal (sub maximal heart rate) unless distressing cardiovascular symptoms supervened.

Arterial blood pressure (ABP) was measured by using Korotkoff method and a computerized ECG analysis system "Kaunas_load", developed at the Kaunas University of Medicine, Institute of Cardiology, and employed for 12 lead ECG recording and analysis. The changes in RR interval or heart rate (HR), JT interval, STsegment depression and in the ratio of intervals JT / RR were analysed. A computerized program allowed to evaluate the velocity of adaptation of cardiovascular system to exercise, i.e. the index of velocity of adaptation $\left(\mathrm{V}_{\mathrm{Ad}}\right)$, by calculating the difference between the relative changes of JT interval and $\mathrm{RR}$ interval as a difference:

$$
\mathrm{V}_{\mathrm{Ad}}=\left(\mathrm{JT}_{\mathrm{i}} / \mathrm{JT}_{0}\right) 100 \%-\left(\mathrm{RR}_{\mathrm{i}} / \mathrm{RR}_{0}\right) 100 \% \text {. }
$$

The significance of the difference between parametrical and nonparametrical values was evaluated by computing t criterion. The difference was considered statistically reliable, when $p$ was $<0.05$ (95 CI).

\section{RESULTS}

Table 1 presents the values of cardiovascular indices registered during the bicycle ergometry. The results obtained during the bicycle ergometry of incremental increase in provocative workload showed that the greatest ability to perform the incremental workload was in the endurance group. All the participants of the experiment underwent a workload of $300 \mathrm{~W}$ and the $60 \%$ of them even $350 \mathrm{~W}$. The least working capacity was shown among the participants in the non-athlete group. They were able to reach the workload of $200-250 \mathrm{~W}$. We found no significant differences $(p>0.05)$ between sprint and

\begin{tabular}{|c|c|c|c|c|c|}
\hline Subject group & HR, b / min & $\begin{array}{c}\text { ST-segment } \\
\text { depression, } \\
\mathrm{mV}\end{array}$ & $\begin{array}{c}\text { JT interval, } \\
\text { ms }\end{array}$ & JT / RR & $\mathrm{ABP}, \mathrm{mmHg}$ \\
\hline Non-athlete group & $\frac{78.3 \pm 2.5}{178.2 \pm 4.7}$ & $\frac{0.07 \pm 0.01}{0.6 \pm 0.05}$ & $\frac{268.2 \pm 3.2}{163.1 \pm 4.6}$ & $\frac{0.358 \pm 0.01}{0.631 \pm 0.03}$ & $\frac{123.2 / 75.6}{198.2 / 31.6}$ \\
\hline Endurance group & $\frac{66.4 \pm 2.3}{172.4 \pm 1.8}$ & $\frac{0.05 \pm 0.01}{0.26 \pm 0.07}$ & $\frac{294.3 \pm 3.3}{161.2 \pm 1.2}$ & $\frac{0.343 \pm 0.01}{0.621 \pm 0.02}$ & $\frac{121.6 / 78.1}{193.7 / 35.0}$ \\
\hline Sprint group & $\frac{79.4 \pm 2.6}{178.2 \pm 2.9}$ & $\frac{0.08 \pm 0.01}{0.42 \pm 0.06}$ & $\frac{266.5 \pm 3.1}{165.2 \pm 3.4}$ & $\frac{0.353 \pm 0.01}{0.633 \pm 0.02}$ & $\frac{120.5 / 80.2}{189.4 / 36.6}$ \\
\hline $\begin{array}{l}\text { Combative sport } \\
\text { group }\end{array}$ & $\frac{72.7 \pm 2.5}{178.4 \pm 2.8}$ & $\frac{0.10 \pm 0.01}{0.41 \pm 0.06}$ & $\frac{265.7 \pm 4.0}{162.9 \pm 2.3}$ & $\frac{0.351 \pm 0.01}{0.628 \pm 0.03}$ & $\frac{122.6 / 35.8}{203.1 / 34.5}$ \\
\hline
\end{tabular}

Table 1. Cardiovascular indices registered during the bicycle ergometry

\begin{tabular}{|l|c|c|c|}
\hline \multirow{2}{*}{\multicolumn{1}{c|}{ Subject group }} & \multicolumn{3}{|c|}{ Exercise Test } \\
\cline { 2 - 4 } & Roufier Test & $\begin{array}{c}\text { 30-s vertical jump } \\
\text { Test }\end{array}$ & $\begin{array}{c}\text { Bicycle ergometry } \\
\text { (graded stress) }\end{array}$ \\
\hline Non-athlete & $21.4 \pm 1.33$ & $22.1 \pm 1.33$ & $21.7 \pm 1.34$ \\
\hline Endurance group & $19.8 \pm 1.34$ & $20.6 \pm 1.31$ & $20.1 \pm 1.32$ \\
\hline Sprint group & $16.3 \pm 1.33$ & $16.9 \pm 1.32$ & $16.4 \pm 1.34$ \\
\hline Combative-sport group & $17.2 \pm 1.29$ & $17.8 \pm 1.30$ & $17.3 \pm 1.29$ \\
\hline
\end{tabular}

Table 2. The values in velocity of adaptation $\left(V_{\text {Ad }}\right)$ of cardiovascular system at onset of Roufier test (aerobic workout), 30-second all-out test in jumping (anaerobic workout) and bicycle ergometry (graded stress) 
Fig. Mobilization of cardiovascular function during various exercise tests (Maximal values in changes of the ratio JT / RR)

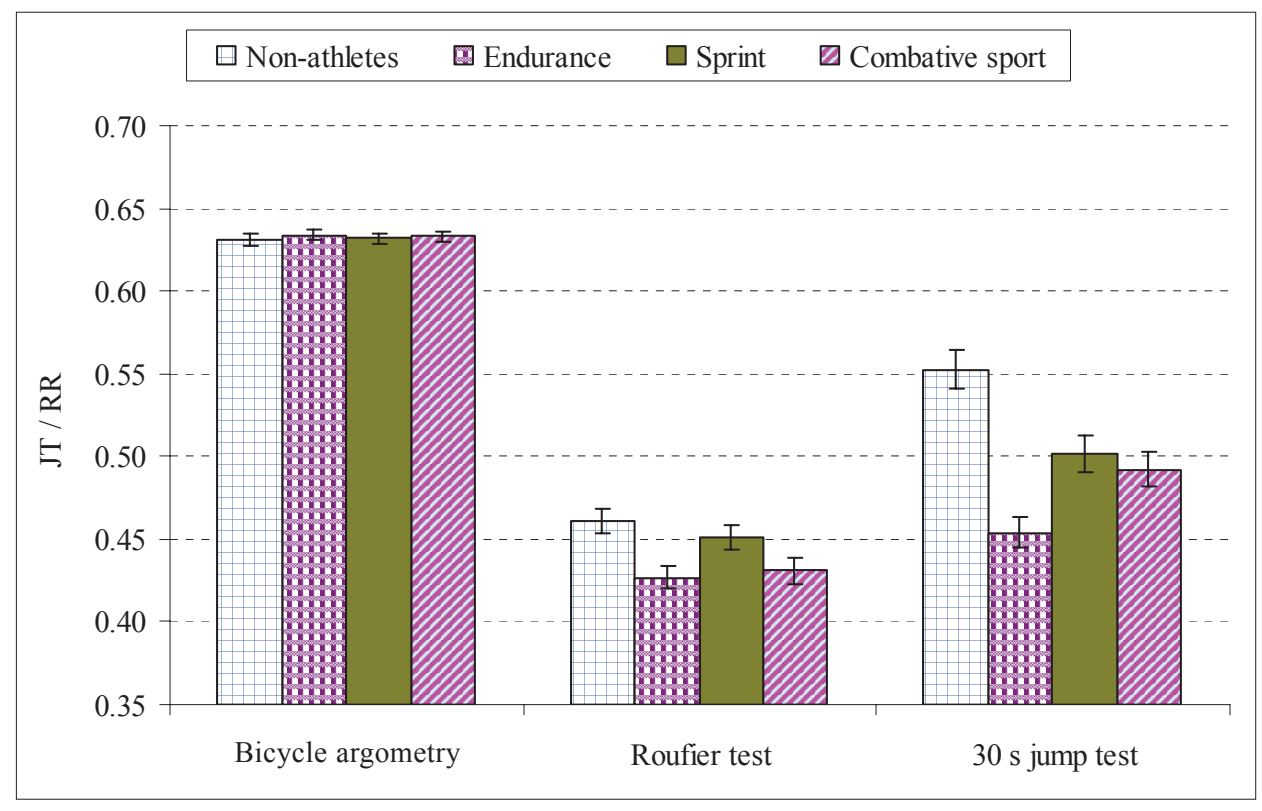

combative sport groups. The participants of these cohorts underwent a workload of $250-300 \mathrm{~W}$.

There were no statistically significant differences in heart rate, arterial blood pressure values and JT / RR values between the groups $(p>0.05)$ at the end of the workout of incremental increase in workload. There is evidence that a full mobilization of functional abilities of the body has been reached. The differences between cohorts were manifested in values of ST-segment depression at the end of workout, in values of changes of cardiovascular indices in the same grades of the task, in the relative changes of cardiovascular indices in the performance, i. e. developed power on bicycle ergometer.

The results presented in Table 2 demonstrate that the velocity of adaptation at onset of exercise depends on the residual effects of training but not on the type of exercise-test. The significant differences between the values in the velocity of adaptation in response to exercising were not found when three various test protocols were used (Roufier test, 30 -second duration maximal vertical jump test, or incremental increase in workload). The fastest adaptation at onset of exercise was in sprint group $(16.3 \pm 1.33 \%)$. The values of velocity of adaptation in the endurance group were $19.8 \pm 1.34 \%$. The difference between sprint and endurance cohorts was statistically significant $(\mathrm{p}<0.05)$. The velocity of adaptation in the group of non-athletes were the slowest $-21.4 \pm 1.33 \%$. Summing up, the faster adaptation at onset of exercise is characteristic of sprint and combative sport, compared to endurance or non-athlete cohorts.
Figure 1 presents the comparison of the mobilization of cardiovascular function during the various exercise tests. There were no differences in the ratio JT interval and RR interval (JT / RR between the cohorts at the end of graded stress, i. e. when maximal mobilization of muscular and cardiovascular systems was obtained. On the other hand, the greatest difference between the cohorts was revealed in a 30 -second duration all-out maximal vertical jump test. The greatest values were in the group of non-athletes and the least in endurance group. The difference between these cohorts was statistically significant $(\mathrm{p}<0.05)$. The Roufier test also revealed the differences between the cohorts.

\section{DISCUSSION}

Concerning the problem of the evaluation of the peculiarities in mobilization of body functioning during exercising the two factors are important: first, the velocity of adaptation at onset of exercise, and second, to what extent the body function was mobilised.

The fast mobilization of body functions at onset of exercise is very important in many kinds of sport and there are a lot of situations in competitive sport when this ability is a decisive factor or important element of functional capability. There are not so many integral methods designed for the assessment of individual peculiarities of mobilization of body functions during exercising. Energy system approach is fit enough for the explanation of 
matters but it is difficult to use it in practice. On the other hand given repeated reproduction over the years, these early attempts have lead to 2 common misconceptions in the exercise science and coaching professions (Green, 1995). First, that the energy systems respond to the demands of intense exercise in an almost sequential manner, and second, that the aerobic system responds slowly to these energy demands, thereby playing little role in determining performance over short durations. More recent research suggests that energy is derived from each of the energyproducing pathways during almost all exercise activities. The duration of all-out exercise at which equal contributions are derived from the anaerobic and aerobic energy systems occurs is considerably earlier than has traditionally been suggested. (Spencer et al., 1996; Gastin, 2001; Green, 1995). We must point out that the last year studies have shown a great importance of complexity in body functioning (Tulpo et al., 2002; Vainoras, 2002). Since the cardiovascular system is one of the constituent parts and a holistic system of the body therefore the reactions of cardiovascular system to constant-load tests or all-out tests allows one to assess the functional capabilities and functional peculiarities of the body (Vainoras, 2002)

The results obtained in this study have shown what a significant role in developing and improving the velocity of adaptation of cardiovascular system at onset of exercise is played by the exercise type or type of adaptation. The main differences in the content of training between the sprint and endurance cohorts consist in prevailing the interval methods of training in sprint cohort and sustained exercise in endurance events (Платонов, 2004). Sudden changes in the intensity of workloads during the fight are typical of combative events. Thus, these changes could be a possible explanation of the differences in values of the velocity of adaptation between the endurance and sprint or combative cohorts found in this study.

Individual peculiarities and differences between various cohorts can be assessed making use of the index of velocity of adaptation $\left(\mathrm{V}_{\mathrm{Ad}}\right)$, which represents the difference between the relative changes of RR and JT intervals of ECG. Our previous studies (Poderys 2000, 2002; Poderys et al., 2005) have shown that the velocity of adaptation at onset of exercise depends rather on the functional state or residual effects of training than on the type of exercise-test. During the study designed to evaluate the changes in velocity of adaptation in sprint cohort significant changes under the influence of concentrated heavy training loads have been found, i. e. $16.3 \pm 1.33 \%$ before training, $26.2 \pm 1.42 \%$ - after 2 -wk of heavy training, and $20.1 \pm 1.35 \%$ - after one week of recovery accordingly (Poderys, 2002). All this allows us to conclude that individual peculiarities and differences between cohorts in the velocity of adaptation of cardiovascular system at onset of exercise can be evaluated making use of the difference between the relative changes of RR and JT intervals of ECG.

The studies designed to assess the individual peculiarities of body functioning during the workloads usually have a task to evaluate to what extent the body function was mobilised during the performance of the task. Absolute values such of heart rate during exercising can be used for these purposes. Such methods are practical but not precise for outlining to what extent the mobilisation of cardiovascular system occurred (Vainoras, 1996, 2002; Poderys, 2000). A special study performed by Bochkov (Бочков) in 1986 showed that activation of physiological systems could be expressed by normalised values in the ratio of underlying indices of the physiological system. These underlying indices of cardiac function can be the ratio of JT and RR intervals (Vainoras, 1996) The JT interval is not independent of the ventricular depolarisation pattern and can be used as an accurate means of following the duration of ventricular depolarisation (Banker et al., 1997) and its changes interrelate with the changes in the intensity of metabolism (Vainoras, 1996). The results obtained during this study have shown that the ratio JT / RR can be useful for outlining to what extent a cardiovascular function was mobilised. As it was found during the incremental increase in workload (till the inability to continue the task) the ratio in JT / RR has varied very closely or even coincided as it was established by Bochkow in 1986. Accordingly to Bochkow these biological constants can be expressed mathematically $(1 / \mathrm{e}=0.368$ and $1-1 / \mathrm{e}=0.632)$. When performing dosed workloads (Roufier test - aerobic workout) and during a 30 -second all-out test in jumping (anaerobic workout) the changes in ratio JT / RR were in dependence on the performance abilities (training experience) and functional state. This is clear evidence, as the ratio of JT and RR intervals 
(JT / RR) of ECG provides the information concerning the dynamics of mobilization of cardiovascular system during the workouts.

\section{CONCLUSIONS}

1. The velocity of adaptation of cardiovascular system at onset of exercise depends on the type of adaptation to exercise type. A faster adaptation at onset of exercise is rather characteristic of sprint and combative sports than representatives of endurance or non-athletes.
2. The change in ratio of JT interval and RR interval (JT / RR) of ECG allows to assess the dynamics of mobilization of cardiovascular system during the workouts.

3. A significant property of recovery after physical loads is an adequate sequence of recovery of cardiovascular system functional indicators and this sequence does not depend on the type of adaptation to exercise. The faster recovery is the ratio JT / RR, then the recovery of the heart rate (RR interval), then - JT interval.

\section{REFERENCES}

Banker, J., Dizon, J., Reiffel, J. (1997). Effects of the ventricular activation sequence on the JT interval. American Journal of Cardiology, 79 (6), 816-819.

Biggiero, L. (2001). Source of complexity in human systems. Journal of Non-linear Dynamics. Psychology and Life Sciences, 5 (1), 379.

Gastin, P. B. (2001). Energy system interaction and relative contribution during maximal exercise. Sports Medicine, 31 (10), 725-741.

Green, S. (1995) Measurement of anaerobic work capacities in humans. Sports Medicine, 19 (1), 32-42.

Hedelin, R., Kentta, G., Wiklund, U., Gjierle, P., HeriksonLarsen, K. (2000). Short-term over training: Effect of performance, circulatory responses, and heart rate variability. Medicine \& Science in Sports \& Exercise, 32, 1480 - 1484.

Hughson, R. L., Tschakovsky, M. E. (1999). Cardiovascular dynamics at the onset of exercise. Medicine \& Science in Sports \& Exercise, 31 (7), 1005-1010.

Poderys, J. (2002). Acute and chronic adaptation of cardiovasdcular function to sprint or andurance training. Ugdymas. Kūno kultūra. Sportas, 3, 44-48.

Poderys, J. (2000). Acute and Chronic Adaptation of Cardiovascular System to Exercise: Summary of Research Report Presented for Habitation. Kaunas: Kaunas University of Medicine.

Poderys, J., Buliuolis, A., Poderytè, K., Sadzevičienė, R. (2005). Mobilization of cardiovascular function during the constant-load and all-out exercise tests. Medicina (Kaunas), 41, 1048-1053.

Porter, H., Louisy, F., Laude, D., Berthelot, M., Guezennec, C. Y. (2001). Intense endurance training on heart rate and blood pressure in runners. Medicine \& Science in Sports \& Exercise, 33, 1120-1125.
Rothe, C. F., Gersting, J. H. (2002). Cardiovascular interaction: An interactive tutorial and mathematical model. Journal of Advances in Physiology Education, 26 (2), 98-109.

Spencer, M. R., Gastin, P. B., Payne, W. R. (1996). Energy system contribution during 400 to 1500 metres running. IAAF quarterly. New Studies in Athletics, 17 (4), 5965

Tulpo, M. P., Hughson, R. L., Miakikalio, T. H. (2002). Effects of exercise and passive head - up tilt on fractal and complexity properties of heart rate dynamics. AJP Heart and Circulatory Physiology, 280 (3), H $18081-$ 1087.

Vainoras, A. (1996). Investigation of the Heart Repolarisation Process during Rest and Bicycle Ergometry (100-lead and standard 12-lead ECG data): Synopsis of a D. Sc. habil. thesis. Kaunas. P. 64.

Vainoras, A. (2002). Functional model of human organism reaction to load evaluation of sportsmen training effect. Ugdymas. Küno kultūra. Sportas, 3 (44), 88-93.

Ursino, M. (1998). Interaction between carotid baroregulation and the pulsating heart: A mathematical model. American Journal of Physiology, 44, 1733-1747.

Бочков, В. Г. (1986). Многовариантность регулирования в биологических системах и новые физиологическые константы: автореферат диссертации на соискание учёной степени кандидата биологических наук. Киев. C. 16 .

Платонов, В. Н. (2004). Система подготовки спортсменов в олимпийском спорте. Общая теория и её практическое приложение. Киев: Олимпийская литература. С. 808. 


\title{
ADAPTACIJOS POVEIKIS ŠIRDIES IR KRAUJAGYSLIŲ SISTEMOS MOBILIZACIJOS BEI ATSIGAVIMO YPATYBE்MS ATLIEKANT FIZINIUS KRŪVIUS
}

\author{
Alfonsas Buliuolis, Jonas Poderys, Mindaugas Ežerskis, Kristina Poderytė, Birutė Miseckaitė \\ Lietuvos kūno kultūros akademija, Kaunas, Lietuva
}

\begin{abstract}
SANTRAUKA
Tyrimo tikslas - nustatyti širdies ir kraujagysliu sistemos (ŠKS) mobilizacijos ypatybes, kai nesportuojantys asmenys $(\mathrm{n}=17)$ ir treniruoti dvikovių šakų sportininkai $(\mathrm{n}=21)$, adaptuoti prie greitumo $(\mathrm{n}=17)$ arba ištvermès $(\mathrm{n}=21)$ fizinių krūvių, atlieka dozuoto ar maksimalaus fizinio krūvio mèginius. Tiriamiesiems atliekant Rufjè, 30 s trukmès vertikalių šuoliu ir pakopomis kiekvieną minutę didinamo fizinio krūvio mėginius veloergometru buvo matuojama AKS ir kompiuterine EKG registravimo ir analizès sistema „Kaunas - krūvis“ registruojama 12 standartiniu elektrokardiogramos atvadų. Naudota kompiuterinè EKG analizės programa išmatuodavo ne tik absoliučias vertinamų EKG rodikliu reikšmes, bet ir daugumą santykinių reikšmių, tarp jų JT ir RR intervalų santykị (JJ / RR) bei adaptacijos greičio rodiklį, vertinamą kaip skirtumą tarp elektrokardiogramos JT ir RR intervalų kaitos: $\mathrm{V}_{\mathrm{Ad}}=\left(\mathrm{JT}_{\mathrm{i}} / \mathrm{JT}_{0}\right) 100 \%-\left(\mathrm{RR}_{\mathrm{i}} / \mathrm{RR}_{0}\right) 100$.

Tyrimo rezultatai parode, kad organizmo adaptacijos prie fizinio krūvio greitis $\left(\mathrm{V}_{\mathrm{Ad}}\right.$ priklauso nuo liekamujų treniruotès veiksmų ir nuo adaptacijos prie fizinių krūvių pobūdžio, tačiau visiškai nepriklauso nuo to, koks fizinio krūvio testas yra atliekamas. Mažiausios $\mathrm{V}_{\mathrm{Ad}}$ reikšmès buvo aptiktos sprinto sportininku grupejje $-16,3 \pm 1,33 \%$. Ištvermès grupeje $\mathrm{V}_{\mathrm{Ad}}$ vidutiniškai siekè $19,8 \pm 1,34 \%$. Skirtumas tarp greitumo ir ištvermès grupių rodiklių buvo statistiškai patikimas $(\mathrm{p}<0,05)$. Didžiausios $\mathrm{V}_{\mathrm{Ad}}$ rodiklio reikšmès buvo nustatytos nesportuojančiuju grupejje - 21,4 $\pm 1,33 \%$. Vertinant elektrokardiogramos JT ir RR intervalu santykị nebuvo aptikta skirtumo tarp grupių, atliekant pakopomis didinamą krūvị, t. y. kai buvo pasiekta maksimali raumenų ir ŠKS sistemų mobilizacija. Tačiau skirtumas tarp grupių išryškèjo vertinant šio rodiklio kaitą atliekant $30 \mathrm{~s}$ vertikalius šuolius maksimaliomis pastangomis - nustatyti statistiškai reikšmingi $(\mathrm{p}<0,05)$ tarpgrupiniai rodikliu skirtumai.

Išvados: 1 - vertinamą adaptacijos greičio rodiklį daugiau lèmė organizmo adaptacijos prie fiziniu krūvių pobūdis ir nepriklausẻ nuo fizinio krūvio mėginio pobūdžio: dvikovių šakų sportininkai ir asmenys, adaptuoti prie greitumo krūvių, greičiau prisitaiko nei asmenys, adaptuoti prie ištvermès fiziniu krūvių; 2 EKG intervalų santykio JT / RR kaita fizinio krūvio metu rodo širdies ir kraujagyslių sistemos mobilizacijos laipsni; 3 - EKG rodiklių atsigavimo po fizinių krūvių nuoseklumas nepriklauso nuo adaptacijos prie fizinių krūviu pobūdžio: pirmiausia atsigauna JT / RR rodiklių santykis, paskui $n-R R$ intervalas, vèliausiai JT intervalas.
\end{abstract}

Raktažodžiai: adaptacija, širdies ir kraujagyslių sistema, atsigavimas, JT intervalas.

Gauta 2008 m. spalio 1 d.

Received on October 1, 2008

Alfonsas Buliuolis

Lithuanian Academy of Physical Education

(Lietuvos kūno kultūros akademija)

Sporto str. 6, LT-44221 Kaunas

Lithuania (Lietuva)

$\mathrm{Tel}+37037302650$

E-mail a.buliuolis@lkka.lt 